\title{
Budapest 2001
}

\author{
By Ron Holloway
}

Fall 2001 Issue of KINEMA

\section{HUNGARIAN FILM WEEK BUDAPEST}

Awarded both the Main Prize of the Hungarian Jury and the Gene Moskowitz Critics Prize at the $32^{\text {nd }}$ Hungarian Film Week (1-6 February 2001), Béla Tarr's Werckmeister Harmoniak (The Werckmeister Harmonies) crowned the Budapest festival with one of the finest European films produced in 2000. The two-and-a-halfhour screen adaptation of Laszlo Krasznahorkai's novel The Melancholy of Resistance (published in 1989) was four years in the making (1996-2000) and could be brought to completion only with coproduction assistance of visionary Berlin producer Joachim von Vietinghoff. And who else but Béla Tarr, Hungary's leading avant-garde filmmaker, would spend three years (1991-94) bringing another Krasznahorkai novel, Satantango (published in 1985), to the screen in an hypnotic seven-and-a-half-hour tour-de-force?

Queried at Cannes 2000, where The Werckmeister Harmonies premiered at the Directors Fortnight, why his fascination for Laszlo Krasznahorkai's literary oeuvre, Béla Tarr simply answered: "We complement each other." Together over the last twelve years, they have collaborated on no less than four screen adaptations: Damnation (1987), The Last Boat (1989), a short feature for the City Life series sponsored by the Rotterdam festival, the acclaimed masterpiece Satantango (1994), and now The Werckmeister Harmonies. The important films are the thematic, stylistic trilogy Damnation, Satantango, and The Werckmeister Harmonies -all photographed in haunting black-and-white (cameraman Gabor Medvigy) and set in isolated blotches on a landscape inhabited by human wrecks.

Two approaches to the Tarr-Krasznahorkai trilogy are valid. Either you view them as statements on the downfall of the decaying socialist order in any industrial metropolis of Central and Eastern Europe. Or you can accept them as apocalyptic parables that apply equally well to social and environmental ills of the capitalist West. Match the mud-splattered "Titanic Bar" in Damnation with the abandoned agricultural plant in Satantango or the dirt-caked provincial town in The Werckmeister Harmonies, and you are left with the same disturbing image of the world sinking into oblivion. Add to this the arrival of a "Messiah" on the scene, hyped by a great stuffed whale hidden in a circus tent, and you have what might be easily interpreted as the biblical equivalent of the Apocalypse. Shot in German, then dubbed in Hungarian for home release and festival distribution, this is one of those few instances in which both versions stand by themselves as works of cinematic art.

Nothing else of note could be found at Budapest this year. So long as warring parties in the government and film associations fail to reach an agreement on the range, strategy, and efficacy of a film fund to aid producers and directors, the promised new film law will remain in limbo to the detriment of all concerned. As a consequence, the veteran directors seem tired and have nothing more meaningful to say. Miklós Jancsó's Last Supper at the Arabian Gray Horse picks up where his Lord's Lantern in Budapest (1998) left off: Kapa and Pepe, a pair of absurd heroes, look down on the city from the Liberty Bridge over the Danube to talk about life and everyday wonders -- like the millennium fireworks. Márta Meszáros's The Miraculous Mandarin, a 35-minute segment of an unfinished project, is a tale of love and passion set against Béla Bartók music and Chinese choreography. And Peter Gothar's Passport, a tele-feature set in eastern Hungary at the Ukrainian border, comes across as a black comedy on life and mores in rural eastern Europe.

As for the younger generation, some newcomers are well worth watching as promising future talents. Agnes Incze's I Love Budapest follows four "born losers" around the city as the youths seek fun and pleasure to fulfill their daydreams. Ferenc Torok's Moscow Square, set at a Budapest-underground station with the same name, uses an 18th birthday celebration on 27 April 1989 to chronicle a night of rowdy behaviour: car theft, porno videos, party chasing, girls and fights -- as if the low life is an end onto itself. And Peter Timar's Blind Guys, shot at an institute for the blind, recounts how a burnt-out rock musician and a dancer with time on her hands find their way back to the ranks of the creative -- and discover how much they enjoyed the task too. 
As for Hungarian documentaries, Ferenc Moldovanyi's Children of Kosovo -- its original title Deza-Femijet means "children" in Serbian and Albanian -- is remarkable for its rather unusual approach to tragic events in Kosovo over the past year: the savage slaughter of masses of innocent people, particularly children, on both sides of the conflict. A poignant, insightful documentary shot in black-and-white in the spring of 2000, Children of Kosovo is far more than just a children's film about kids in the Balkans -- it's an indictment of man's inhumanity to man.

\section{Author Information}

Ron HOLLOWAY (1933-2009) was an American critic, film historian, filmmaker and correspondent who adopted Europe as his home in the early fifties and spent much of his life in Berlin. He was an expert on the study of German cinema and against all odds produced, with his wife Dorothea, the journal German Film, keeping us up-to-date with the work of directors, producers and writers and the showing of German films around the world.

In 2007, Ron Holloway and his wife were awarded the Berlinale Camera Award. Ron also received the Bundesverdienstkreuz (German Cross of Merit), Polish Rings, Cannes Gold Medaille, the American Cinema Foundation Award, the Diploma for Support of Russian Cinema and an honorary award from the German Film Critics' Association.

Ron was also a valued contributor to Kinema for the past fifteen years. 